\title{
PHYSICOCHEMICAL CHARACTERIZATION, ANTIOXIDANT ACTIVITY AND FINGERPRINTS OF INDUSTRIALIZED "DETOX” MIXED BEVERAGES BY PAPER SPRAY MASS SPECTROMETRY
}

\author{
Eliane Beatriz M. Silva ${ }^{a}$, Rodinei Augusti ${ }^{b}$, Júlio O. F. Melo ${ }^{\mathrm{c}, \text {, }}$, Jacqueline Aparecida Takahashi ${ }^{\mathrm{b}}$ and Raquel L. Bello de \\ Araújo $^{a}$ \\ aDepartamento de Alimentos, Universidade Federal de Minas Gerais, 31270-901 Belo Horizonte - MG, Brasil \\ ${ }^{b}$ Departamento de Química, Universidade Federal de Minas Gerais, 31270-901 Belo Horizonte - MG, Brasil \\ 'Departamento de Ciências Exatas e Biológicas, Universidade Federal de São João Del-Rei, 35701-970 Sete Lagoas - MG, Brasil
}

Recebido em 16/10/2019; aceito em 11/12/2019; publicado na web em 09/03/2020

\begin{abstract}
The objective of this work was to determine the chemical composition, total phenolic compounds content, antioxidant capacity through the ABTS (2,20-azino-bis(3-ethylbenzthiazoline-6-sulphonic acid) method, as well as to evaluate the use of paper spray ionization mass spectrometry (PS-MS) to obtain fingerprints in different brands of mixed industrialized beverage based on fruits and vegetables with "detox" denomination. The carbohydrate contents ranged from $4.17 \%$ (sample D) to $12.72 \%$ (sample G). The differences may be related to the composition and proportion of the ingredients present in each formulation. The contents of total phenolic compounds varied between $26.75 \mathrm{mg} \mathrm{GAE}$ (gallic acid equivalents) $\mathrm{g}^{-1}$ (sample F) to $48.61 \mathrm{mg} \mathrm{GAE} \mathrm{g}^{-1}$ (sample D). The samples A, B and C contain cabbage, spinach and parsley and presented significantly higher phenolic compounds content than the other samples. The antioxidant activity values varied between $1.76 \mu \mathrm{mol} \mathrm{L}^{-1}$ Trolox g-1 (sample B) to $18.95 \mu$ mol L ${ }^{-1} \mathrm{Trolox}_{\mathrm{g}}-1$ (sample E). The brands E, F, and G, that presented higher antioxidant potential, have ingredients pineapple, apple, cabbage, and ginger as common. The analysis of PS-MS allowed for the identification of a number of substances, including organic acids, sugars, and phenolic acids. PS-MS is a relatively simple method, fast and efficient to obtain fingerprints of mixed beverages.
\end{abstract}

Keywords: phenolic compounds; ABTS; mixed beverage; PS-MS.

\section{INTRODUCTION}

The practice of healthy eating is related to, among other factors, the consumption of fruits and vegetables, which contributes to the proper maintenance of health and prevention of diseases. ${ }^{1,2}$ The World Health Organization (WHO, 2016) recommends the consumption of five daily portions of fruits and vegetables. These foods have nutrients such as vitamin $\mathrm{C}$, vitamin $\mathrm{E}$, in addition to carotenoids and phenolic compounds, with recognized antioxidant activity and are associated with the protective effects of human health. ${ }^{3,4}$ The mixture of different fruits and vegetables to obtain differentiated beverages has been studied in order to increase the nutritional quality of the diet since they are rich in nutrients essential for health. ${ }^{5}$ Phenolic compounds are secondary metabolites that are present in vegetables, with a wide variety of chemical structures. The chemical structure of the compounds present an aromatic ring having one or more hydroxyl groups, thus being able to vary from a simple phenolic molecule to a complex polymer of high molecular weight. ${ }^{3,6}$ The main groups are simple phenolics, hydroxybenzoic acids, hydroxycinnamic acids, phenylacetic acids, flavonoids. ${ }^{7}$ Antioxidant compounds have a role in reducing oxidative stress because they can eliminate free radicals directly, as in the case of vitamins, or indirectly, by the minerals that act as cofactors of antioxidant enzymes. ${ }^{8}$ For the identification of bioactive compounds and their antioxidant capacity, there are different methods. For quantification of phenolic compounds, Follin-Ciocalteu reagent, which uses the standard gallic acid curve as reference, can be used. ${ }^{9}$ One of the methods used for the determination of total antioxidant activity uses the radical 2,2-Azino-bis-(3-ethyl-benzothiolin-6-sulfonic acid) (ABTS), as proposed by Rufino et al. ${ }^{10}$ Different analytical techniques are utilized for a more comprehensive characterization of a mixed beverage of fruits and vegetables, including chromatographic methods such as high-performance liquid chromatography (HPLC) coupled to a diode array detector (DAD) and also to a mass spectrometer (HPLC-DAD-MS). ${ }^{11}$ These instrumental methods allow accurate analysis, however, need for careful pre-preparation of samples and high analytical cost. Currently, mass spectrometry with ambient ionization source allows for ultra-fast analysis with low cost and high sensitivity in complex matrices. ${ }^{12}$

Among mass spectrometry techniques, paper spray mass spectrometry (PS-MS), developed by Wang et al. ${ }^{13}$ has been widely used in qualitative-quantitative analyses of substances in complex matrices. A significant advantage of PS-MS is the possibility of rapidly obtaining spectra for a wide range of samples. These spectra, denominated fingerprints, provide a molecular profile of raw material at room temperature and atmospheric pressure. ${ }^{14}$ Mixed fruit and vegetable-based beverages, marketed as "detox", are part of popular detoxification diets that are short-term interventions based on consumption of foods such as fruits, vegetables, soups, juices and mixtures of juices and teas. ${ }^{15}$

According to Klein and Kiat ${ }^{16}$ as of 2014 , there were no scientific studies that proved the potential benefits and risks of this type of diet. Mixed fruit and vegetable drinks are known in the consumer market as detoxifying and can induce consumption and use by the population in search of quality nutrition. Therefore, it is important to study these foods, determining a variable chemical composition according to each case and identifying the presence of bioactive compounds with antioxidant potential. Thus, the present study aimed to determine the chemical composition, total phenolic compounds content and antioxidant activity in addition to the identification of other chemical constituents using PS-MS for differentiation of seven brands of industrialized mixed beverages. 


\section{EXPERIMENTAL}

\section{Experimental design}

Mixed beverages of fruits and vegetables commercialized in food establishments in Belo Horizonte (MG) and food marketing sites were selected. The sample selection process is shown in Figure 1.

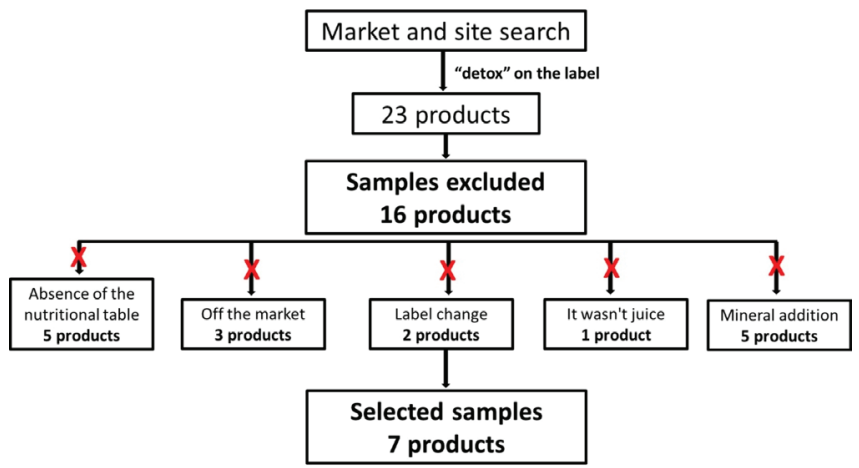

Figure 1. Flowchart of the samples selected for the study

The initial selection was carried out by choosing the products for which the information was included on the label in the sales name "detox juice", and the final selection consisted of the acquisition of all products that had labels with a nutritional table and list of ingredients, seven products of different brands were chosen for the study.

Samples were acquired from three different batches of each product selected. Four products were made up of powder for preparation of mixed beverage (A-D), two consisted of pulp (E and F) and one product was ready for consumption (G). Samples A, B, C and $\mathrm{D}$ were stored at room temperature according to the label instructions. The samples E, F and G were freeze-dried, then adequately sealed to avoid water absorption, and stored under refrigeration between $2-8{ }^{\circ} \mathrm{C}$ until analyses of total phenolics, antioxidant capacity and chemical profile by PS-MS. The list of ingredients present in the selected samples is shown in Table 1.

Chemical characterization of ascorbic acid was performed for the products in the form ready for consumption. The powdered samples, brands $\mathrm{A}, \mathrm{B}, \mathrm{C}$ and $\mathrm{D}$ were reconstituted in water for consumption according to the instructions on the label: "Add $20 \mathrm{~g}$ (1 tablespoon) in $200 \mathrm{~mL}$ of water and stir until dissolution". Samples E and F (pulp) were diluted in $200 \mathrm{~mL}$, mixed in the blender also according to the preparation method on the label and sample $\mathrm{G}$ was "ready for consumption."

The following chemical reagents were used in the experiments: Folin-Ciocalteu, 2,2 '-Azino-bis (3-ethyl-benzotiazoline-6-sulfonic acid (ABTS). Standards were acquired from Sigma Aldrich (São Paulo, SP, Brazil). Methanol HPLC grade was acquired from J. T. Baker (Phillipsburg, NJ, USA) and the chromatographic paper $1 \mathrm{CHR}$ from Whatman (Little Chalfont, Buckinghamshire, UK).

\section{Physicochemical analyses}

Titratable acidity (method $\left.\mathrm{n}^{\circ} 942.15\right), \mathrm{pH}\left(\operatorname{method} \mathrm{n}^{\circ} 981.12\right)$, Soluble solids (method $n^{\circ} 932.12$ ) moisture (method $n^{\circ} 920.151$ ), proteins, (method 920.152) ash (method $\mathrm{n}^{\circ} 940.26$ ) and ascorbic acid (method ${ }^{\circ} 967.21$ ), were determined according to the methods described in the Association of Official Analytical Chemists. ${ }^{17}$ The lipids were analyzed according to the extraction method of Bligh and Dyer ${ }^{18}$ employing methanol, chloroform and water. The total
Table 1. Constituents of the selected samples described in the list of ingredients present on the product labels

\begin{tabular}{|c|c|}
\hline $\begin{array}{l}{ }^{a} \text { Mixed } \\
\text { drinks }\end{array}$ & Ingredients \\
\hline A & $\begin{array}{l}\text { Lyophilized cabbage powder, lyophilized spinach powder, } \\
\text { apple powder, parsley powder, ginger powder, maltodextrin, } \\
\text { dehydrated lemon pulp, anti humectant silicon dioxide, thickener } \\
\text { guar gum, sweetener sucralose, flavoring identical to natural } \\
\text { and natural dye. }\end{array}$ \\
\hline B & $\begin{array}{l}\text { Maltodextrin, dehydrated spinach, dehydrated cabbage, dehy- } \\
\text { drated parsley, dehydrated apple, dehydrated ginger, acidulant } \\
\text { citric acid, guar gum thickener, sweetener sucralose, natural } \\
\text { chlorophyll dye and natural lemon aroma. }\end{array}$ \\
\hline $\mathrm{C}$ & $\begin{array}{l}\text { Maltodextrin, dehydrated spinach, dehydrated cabbage, de- } \\
\text { hydrated parsley, dehydrated apple, dehydrated ginger, citric } \\
\text { acidulant, sweetener sucralose, a natural dye of chlorophyll, } \\
\text { aroma identical to natural lime. }\end{array}$ \\
\hline $\mathrm{D}$ & $\begin{array}{l}\text { Maltodextrin, cabbage powder, dehydrated orange pulp, dehy- } \\
\text { drated apple pulp, parsley powder, ginger powder, chlorophyll } \\
\text { powder, synthetic aroma identical to natural lime, acidulant citric } \\
\text { acid and sweetener sucralose. }\end{array}$ \\
\hline $\mathrm{E}$ & Orange, apple, pineapple, cabbage, lemon mint and ginger. \\
\hline $\mathrm{F}$ & Pineapple, apple, cabbage, ginger, and cucumber. \\
\hline G & $\begin{array}{l}\text { Water, apple pulp, pear and carrot, concentrated pineapple and } \\
\text { lemon juices, polydextrose, coconut water, ginger pulp, cabbage, } \\
\text { mint and cucumber, vitamin E, C, stabilizing pectin, natural } \\
\text { aroma of lemon and natural dye of chlorophyll. }\end{array}$ \\
\hline
\end{tabular}

aMixed drinks: refer to A-G samples of different brands of industrialized mixed drinks.

carbohydrate content, including fiber, was calculated by the difference between 100 and the sum of the percentages of moisture, protein, total fats and ash.

\section{Extraction of polyphenols}

Extraction of the lyophilized samples was performed following the procedure described by Rufino et al. ${ }^{19}$ Initially, $0.5 \mathrm{~g}$ of sample and $1 \mathrm{~mL}$ of methanol solution at $50 \%$ were added in a $2 \mathrm{~mL}$ eppendorf tube. After resting one hour at room temperature, the tubes were centrifuged at $25.406 \times g$ for $15 \mathrm{~min}$ and the supernatants collected. Then, $1 \mathrm{~mL}$ of $70 \%$ acetone solution was added to the residue, and new incubation and centrifugation were performed under the same conditions cited. The supernatants obtained were supplemented with distilled water to $5 \mathrm{~mL}$.

\section{Total phenolic compounds and antioxidant activity}

The extracts obtained were used to determine the phenolic compounds content and to evaluate the antioxidant activity:

Total Phenolics: a volume of $150 \mu \mathrm{L}$ of the sample extract, $3850 \mu \mathrm{L}$ of distilled water and $250 \mu \mathrm{L}$ of Folin-Ciocalteu were mixed in erlenmeyer of $125 \mathrm{~mL}$ and incubated at room temperature for $8 \mathrm{~min}$. Then, $750 \mu \mathrm{L}$ of $20 \%$ sodium carbonate solution was added. After two hours of incubation, the samples were read at $765 \mathrm{~nm}$ and the data were expressed as mg of gallic acid equivalents (GAE) $100 \mathrm{~g}^{-1}$ sample. $^{9}$

ABTS: in a test tube, $30 \mathrm{~mL}$ of the sample extract and $3 \mathrm{~mL}$ of ABTS radical were added. After $6 \mathrm{~min}$ of incubation at room temperature reading of the samples at $734 \mathrm{~nm}$ and Trolox calibration curve was performed. The antioxidant activity was expressed in $\mu$ mol L ${ }^{-1}$ Trolox $\mathrm{g}^{-1}$ sample. ${ }^{19}$ 


\section{PS-MS fingerprints}

A mass spectrometer model LCQ Fleet from Thermo Scientific (São José, CA, USA) was used to carry out the analysis of weight spectroscopy, equipped with a paper spray ionization source. The samples from the seven brands of mixed fruit and vegetable beverage were analyzed in negative and positive ionization modes.

In this analysis, the chromatographic paper was cut in an equilateral triangle shape $(1.5 \mathrm{~cm})$ and positioned in front of the mass spectrometer entrance. This paper was supported by a metal connector and positioned $0.5 \mathrm{~cm}$ away with the aid of a movable platform (XYZ).

This apparatus was connected to a high-voltage source of the spectrometer through a copper wire. Ultimately, $2.0 \mu \mathrm{L}$ of juice was applied on the edge of the triangles, $40.0 \mu \mathrm{L}$ of methanol was transferred to the chromatographic paper and the voltage source was connected for data acquisition. For the analyses, the instrument was operated at a voltage of $+4.0 \mathrm{kV}$ (positive ionization mode) and $-3.0 \mathrm{kV}$ (negative ionization mode); capillary voltage of $40 \mathrm{~V}$; transfer tube temperature of $275^{\circ} \mathrm{C}$; tube lenses voltage of $120 \mathrm{~V}$; and mass range from 100 to $1000 \mathrm{~m} / \mathrm{z}$ (positive ionization mode) and from 100 to $1000 \mathrm{~m} / z$ (negative ionization mode). The ions and their fragments obtained in this analysis were identified based on the data described in the literature. Collision energies used to fragmentize the compounds ranged from 15 to $30 \mathrm{~V}$.

\section{Statistical analysis}

The results obtained were submitted to analysis of variance (ANOVA) and the Tukey test for comparison of means was applied at the significance level $\alpha=0.05$.

\section{RESULTS AND DISCUSSION}

\section{Chemical composition}

There were significant variations among the samples studied. The samples presented moisture values between $86.65 \%$ (Sample G) to $95.36 \%$ (Sample D). The total solids values were between $4.64 \%$ (Sample D) and $13.35 \%$ (Sample G) (Table 2).

Moisture content $87.43 \%$ was reported by Bezerra et al..$^{20}$ in mixed juice of acerola, passion fruit and taperebá. Feiber and Caetano ${ }^{21}$ found similar moisture values to the samples of the three pulps studied, cabbage pulp $98.4 \%$, cabbage, pineapple and mint $91.23 \%$ and cabbage and apple pulp $88.7 \%$.

The contents of carbohydrates, lipids and proteins presented statistical differences that may be related to the proportion of the ingredients present in each formulation. In this study, the values of total carbohydrates refer to carbohydrates and fiber. The carbohydrate values ranged from $4.17 \%$ (Sample D) to $12.72 \%$ (Sample G), and the band $\mathrm{C}$ brands have only one fruit, the apple, and the $\mathrm{D}$ sample has apple and orange. Although this beverage presented two fruits in the formulation, the total solids value was the lowest among all the samples (4.64\%), maybe due to the reduced amount of the fruits used in the beverage. The total lipid contents ranged from $0.04 \%$ (Sample C) to $0.80 \%$ (Sample F) and the protein content ranged from $0.07 \%$ (sample D) to $1.78 \%$ (Sample F). The samples that presented higher protein values (Samples E, F and G) have similar formulations, with four ingredients in common (pineapple, apple, ginger, cabbage).

For mixed juice Bezerra et al. ${ }^{20}$ found $0.29 \%$ lipids, $0.28 \%$ protein and $0.16 \%$ ash. The ash content ranged from $0.08 \%$ (Sample A) to $0.51 \%$ (Sample F). The cabbage is present in all the beverages studied, which may have contributed to increase the ash values. Still, in samples E and G, the presence also of mint as a common ingredient may have elevated the concentration of minerals. Feiber and Caetano ${ }^{21}$ developed three different cabbage-based pulps previously cited and observed that the highest ash value was $0.45 \%$ in cabbage, pineapple and mint pulp, highlighting that the vegetables may have contributed to increasing the mineral content of the beverage.

The $\mathrm{pH}$ values ranged between 3.02 (Sample C) to 4.63 (Sample D), showing significant differences. Samples A, C, E, F and $\mathrm{G}$ presented a more acidic $\mathrm{pH}$, which can be attributed to the presence of lemon and pineapple fruits in the list of ingredients of beverages. According to Brum et al. ${ }^{22}$ although the $\mathrm{pH}$ is not a parameter required by the legislation, it is essential to evaluate it, because it is directly related to the quality of the product.

A study conducted by Carvalho et al.,${ }^{23}$ who evaluated the stability of mixed frozen pulps with five types of fruits at concentrations of $5 \%$ and $10 \%$, found values close to those of the present study, with $\mathrm{pH}$ results between 3.39 and 3.48. Moura et al. ${ }^{24}$ found $\mathrm{pH} 3.45$ in commercial beverage type green smoothie with kiwi, pineapple, lime, green tea, mint and chlorophyll. The samples $\mathrm{E}$ and $\mathrm{G}$ also have pineapple, lime and mint and presented $\mathrm{pH}$ values close to 3.44 and 3.21 , respectively.

The soluble solids variation was between $4.23^{\circ}$ Brix (sample D) and $11.76^{\circ}$ Brix (Sample G), with significant differences between sample $\mathrm{G}$ and the other samples analyzed. This result can be

Table 2. Physicochemical composition of mixed beverage samples in \% values

\begin{tabular}{|c|c|c|c|c|c|c|c|}
\hline & \multicolumn{7}{|c|}{ Samples of mixed fruit and vegetable beverages } \\
\hline & $\mathrm{A}$ & B & $\mathrm{C}$ & $\mathrm{D}$ & $\mathrm{E}$ & $\mathrm{F}$ & G \\
\hline Moisture (\%) & $91.43^{\mathrm{b}}$ & $94.44^{\mathrm{d}}$ & $93.98^{\mathrm{c}}$ & $95.36^{\mathrm{e}}$ & $91.19^{\mathrm{b}}$ & $86.85^{\text {a }}$ & $86.65^{\mathrm{a}}$ \\
\hline Total solids $(\%)$ & $8.56^{\mathrm{c}}$ & $5.55^{\mathrm{a}}$ & $6.01^{\mathrm{b}}$ & $4.64^{\mathrm{a}}$ & $8.80^{\mathrm{d}}$ & $13.14^{\mathrm{e}}$ & $13.35^{\mathrm{f}}$ \\
\hline a'Carbohydrates and fibers (\%) & $7.93^{\mathrm{d}}$ & $4.73^{\mathrm{a}}$ & $5.74^{\mathrm{b}}$ & $4.17^{\mathrm{a}}$ & $7.20^{\mathrm{c}}$ & $9.93^{\mathrm{e}}$ & $12.72^{\mathrm{f}}$ \\
\hline Total lipids (\%) & $0.40^{\mathrm{d}}$ & $0.47 \mathrm{de}$ & $0.04^{\mathrm{a}}$ & $0.28^{\mathrm{bc}}$ & $0.18^{\mathrm{b}}$ & $0.80^{\mathrm{f}}$ & $0.07^{\mathrm{a}}$ \\
\hline Protein $(\%)$ & $0.12^{\mathrm{a}}$ & $0.18^{\mathrm{a}}$ & $0.12^{\mathrm{a}}$ & $0.07^{\mathrm{a}}$ & $0.98^{\mathrm{b}}$ & $1.78^{\mathrm{c}}$ & $0.28^{\text {a }}$ \\
\hline Ashes $(\%)$ & $0.08^{\mathrm{a}}$ & $0.14^{\mathrm{c}}$ & $0.10^{\mathrm{ab}}$ & $0.09^{\mathrm{a}}$ & $0.42^{\mathrm{e}}$ & $0.51^{\mathrm{f}}$ & $0.26^{\mathrm{d}}$ \\
\hline $\mathrm{pH}$ & $3.10^{\mathrm{a}}$ & $4.04^{e}$ & $3.02^{\mathrm{a}}$ & $4.63^{\mathrm{f}}$ & $3.44^{\mathrm{c}}$ & $3.48^{\mathrm{cd}}$ & $3.21^{\mathrm{ab}}$ \\
\hline Soluble solids $\left({ }^{\circ}\right.$ Brix $)$ & $7.75^{\mathrm{d}}$ & $5.40^{\mathrm{b}}$ & $5.40^{\mathrm{b}}$ & $4.23^{\mathrm{a}}$ & $6.25^{c}$ & $4.41^{\mathrm{a}}$ & $11.76^{\mathrm{e}}$ \\
\hline Acidity $(\%)$ & $0.10^{\mathrm{a}}$ & $0.15^{\mathrm{b}}$ & $0.10^{\mathrm{a}}$ & $0.10^{\mathrm{a}}$ & $0.53^{\mathrm{e}}$ & $0 . .25^{\mathrm{c}}$ & $0.33^{\mathrm{d}}$ \\
\hline${ }^{\circ}$ Brix/acidity ratio & 54.2 & 36.3 & 77.5 & 42.3 & 11.85 & 17.78 & 35.45 \\
\hline
\end{tabular}

Averages indicated by equal letters on the same line do not differ from each other. Statistical analysis by Tukey Test, with $\mathrm{P}<0.05$. ${ }^{\mathrm{a}} \mathrm{Carbohydrates}$ calculated by difference. 
explained due to the composition of the beverage, since the sample presented four types of fruit in its formulation, unlike Samples A, $\mathrm{D}, \mathrm{F}$ that presented only two types of fruits in their composition. In a study to evaluate the stability of mixed beverages based on pulp, Carvalho et al..$^{23}$ observed values of $11.80^{\circ}$ Brix and $0.29 \%$ acidity in the formulations also prepared by adding four types of fruits. Silva et al..$^{5}$ found $5.0^{\circ}$ Brix in the in natura cucumber pulp. Moreover, it was found that the increase in the proportion of watermelon causes an increase in soluble solids, reaching $8.0^{\circ}$ Brix in the mixture of $90 \%$ watermelon and $10 \%$ cucumber. Faraoni et al. ${ }^{25}$ found total soluble solids values in acerola frozen pulp of $5.50^{\circ} \mathrm{Brix}$ and guava $7.10^{\circ} \mathrm{Brix}$, values close to Samples A, B and C of the present study that has one or two fruits in the composition.

The total titratable acidity was expressed in citric acid because it is the organic acid present in greater quantity in the composition of the juices. This parameter influences the flavor, odor and stability of the products. The total acidity values differed statistically among the Samples, being $0.10 \%$ for Samples A, C and D. Sample E acidity reached $0.53 \%$. The highest acidity of Samples E $(0.53 \%)$ and G $(0.33 \%)$ can be explained by the presence of lemon and pineapple, which are high acidity fruits. The values of the other Samples that were less acidic were compatible with data reported by Machado et al. ${ }^{26}$ who found acidity in the mixed beverage of commercial fruits and vegetables varying from $0.13 \%$ to $0.26 \%$. Silva et al. ${ }^{5}$ found $0.10 \%$ citric acid in mixed cucumber and watermelon juice, and the formulation contained $50 \%$ of each, values close to those of the present study.

The relationship between SS/TA reveals the palatability and the higher the relationship, the better the flavor of the product. The relationship obtained between the Samples varied according to the sample evaluated, being between 11.85 - 77.50. The present study analyzed mixed beverages with common ingredients (cabbage, apple and ginger) in the seven Samples. The elevated values of this parameter indicate less acidic juices. ${ }^{27}$ The variations observed are due to the different combinations of fruits and vegetables used since each has its particular characteristics. It was observed that the values reported in the literature are close to the data obtained in the present study. The mixed beverage of fruits and vegetables can be considered a new product in the market and has no standard of identity and quality (PIQ) established for comparison of the values for proteins, lipids, ash; however, the values found are within the expected range for fruit-based beverages with juices and refreshments.

\section{Total phenolic compounds and antioxidant activity}

The levels of phenolic compounds and antioxidant potential, as well as the ascorbic acid content are shown in Table 3.

The contents of total phenolic compounds varied statistically from $26.75 \mathrm{mg} \mathrm{GAE}$ g-1 (sample F) to $48.61 \mathrm{mg} \mathrm{GAE}$ g-1 (sample D). Sample D presented higher content, with cabbage and parsley, Samples A, B and C, contained cabbage, spinach, parsley and also presented higher levels of bioactive compounds (Table 2). Leafy vegetables contain high levels of glucosinolates ${ }^{28}$ which may have contributed to these results. Murador et al. ${ }^{29}$ found $49.2 \mathrm{mg}$ GAE g-1 in raw cabbage leaf samples, similar to values $46.65 \mathrm{mg}$ GAE g-1 (Sample A) and $48.61 \mathrm{mg}$ GAE g-1 (Sample D).

These results were inferior to those reported by Machado et al. ${ }^{26}$ who compared artisanal mixed beverage of fruit and vegetables to mixed beverage with the denomination "detox" on the label finding $81.38 \mathrm{mg} \mathrm{GAE} \mathrm{g}^{-1}$ and $70.48 \mathrm{mg} \mathrm{GAE} \mathrm{g}^{-1}$ respectively.

The antioxidant activity values varied significantly between 1.76 (Sample B) and $18.95 \mu$ mol L-1 Trolox. g-1 (Sample E). The Samples E, F and G, exhibited higher antioxidant potential and presented, as common ingredients, pineapple, apple, kale and ginger. The presence of four fruits was a common factor among the samples with the best results. Fu et al..$^{30}$ evaluated 62 fruit types and concluded that the antioxidant capacity of fruits is varied. In that study, the combination of different fruits increased the antioxidant capacity of the mixed beverage samples.

The most significant result of the antioxidant capacity determined by the ABTS method were $13.56 \mu$ mol L $\mathrm{L}^{-1}$ Trolox g-1 (sample F), 17.64 $\mu \mathrm{mol} \mathrm{L}{ }^{-1}$ Trolox g-1 (Sample G) and $18.95 \mu \mathrm{mol} \mathrm{L}^{-1}$ Trolox g-1 (Sample E). Pineapple, apple and ginger are a common ingredient present in the three samples that obtained the highest antioxidant capacity results. This fruit was studied by Bamidele and Faso- gabon ${ }^{31}$ who, evaluating the antioxidant capacity by the ABTS obtained values of $5.62 \mu \mathrm{mol}$ Trolox/g for a mixture of large tomato (typical in Nigeria) and pineapple (30:70). They observed that the higher the proportion of pineapple juice, the greater the antioxidant capacity, suggesting that the pineapple was the primary antioxidant source of the beverage. Carvalho et al. ${ }^{24}$ evaluated mixed tropical fruit pulps finding $13.54 \mu \mathrm{mol} \mathrm{L}^{-1}$ Trolox $\mathrm{g}-1$, near the value found for Sample F.

Concerning ascorbic acid, the levels varied significantly between 21.93 mg. $100 \mathrm{~g}-1^{1}$ (Sample C) to $73.68 \mathrm{mg} .100 \mathrm{~g}^{-1}$ (Sample G). Values similar to Samples A, B, E and F were reported by Faraoni et al. ${ }^{25}$ who obtained a general mean of ascorbic acid of $45.90 \mathrm{mg} .100 \mathrm{g-}{ }^{1}$, in mixtures of the frozen pulp of guava, mango and acerola.

\section{Chemical profile of mixed beverages by PS-MS}

The PS-MS proved to be efficient to obtain fingerprints of the evaluated beverage samples. Examples of mass spectra obtained in the positive and negative ionization modes are shown in Figure 2 (Sample B).

Based on the fragmentation profile presented, the ions with $\mathrm{m} / \mathrm{z}, 383$ and 399 were classified as Syringoyl hexoside and 4-Hydroxy-2,5dimethyl-3(2H)-furanone malonyl, respectively. These compounds were previously found by Difonzo et al..$^{32}$ employing HPLC-DAD(HR)-ESI-MS for analysis of pineapple juices. It is also noteworthy that in the present study, syringoyl hexoside was found in $57 \%(\mathrm{n}=$ 4) of the beverages evaluated, and presence of pineapple in Sample $\mathrm{G}$ stands out. Table 4 presents the proposed identification for the ions detected by (+) PS-MS.

The identification attributed to the ions found from the PS-MS analysis in the negative mode is shown in Table 5.

Table 3. Mean results for phenolic compounds, antioxidant capacity and ascorbic acid of seven samples and mixed beverages

\begin{tabular}{|c|c|c|c|c|c|c|c|}
\hline & \multicolumn{7}{|c|}{ Mixed beverage samples } \\
\hline & A & B & $\mathrm{C}$ & $\mathrm{D}$ & $\mathrm{E}$ & $\mathrm{F}$ & G \\
\hline Phenolic compounds (mg a AGE $100 \mathrm{~g}^{-1}$ ) & $46.65^{\text {cde }}$ & $43.95^{\text {cde }}$ & $44.65^{\text {cde }}$ & $48.61^{\mathrm{b}}$ & $35.96^{\mathrm{bc}}$ & $26.75^{\mathrm{a}}$ & $40.39^{\mathrm{cd}}$ \\
\hline${ }^{\mathrm{b}}$ ABTS ( Trolox. $\mathrm{g}^{-1} \mu \mathrm{mol} \mathrm{L} \mathrm{L}^{-1}$ ) & $3.37^{\mathrm{bc}}$ & $1.76^{\mathrm{a}}$ & $2.95^{\mathrm{b}}$ & $4.90^{\mathrm{d}}$ & $18.95^{\mathrm{g}}$ & $13.56^{\mathrm{e}}$ & $17.64^{\mathrm{f}}$ \\
\hline Ascorbic acid $\left(\mathrm{mg} 100 \mathrm{~g}^{-1}\right)$ & $45.61^{\mathrm{c}}$ & $43.86^{\mathrm{c}}$ & $21.93^{\mathrm{a}}$ & $35.09^{\mathrm{b}}$ & $51.75^{\mathrm{cd}}$ & $48.25^{\mathrm{c}}$ & $73.68^{\mathrm{e}}$ \\
\hline
\end{tabular}

Averages indicated by same letters on the same line do not differ from each other. Statistical analysis by Tukey Test, with $\mathrm{P}<0.05$. ${ }^{\mathrm{a}} \mathrm{GAE}$ : gallic acid equivalents.

bABTS: (2.2'-azinobis-3-ethyl-benzothiazine-6-sulfonate). 


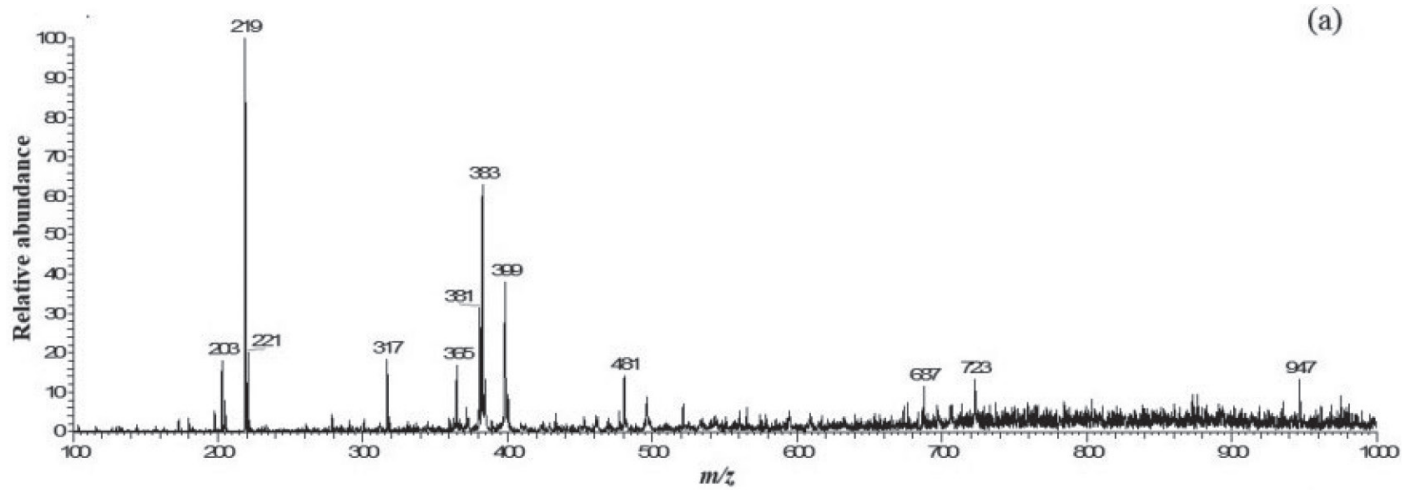

(b)

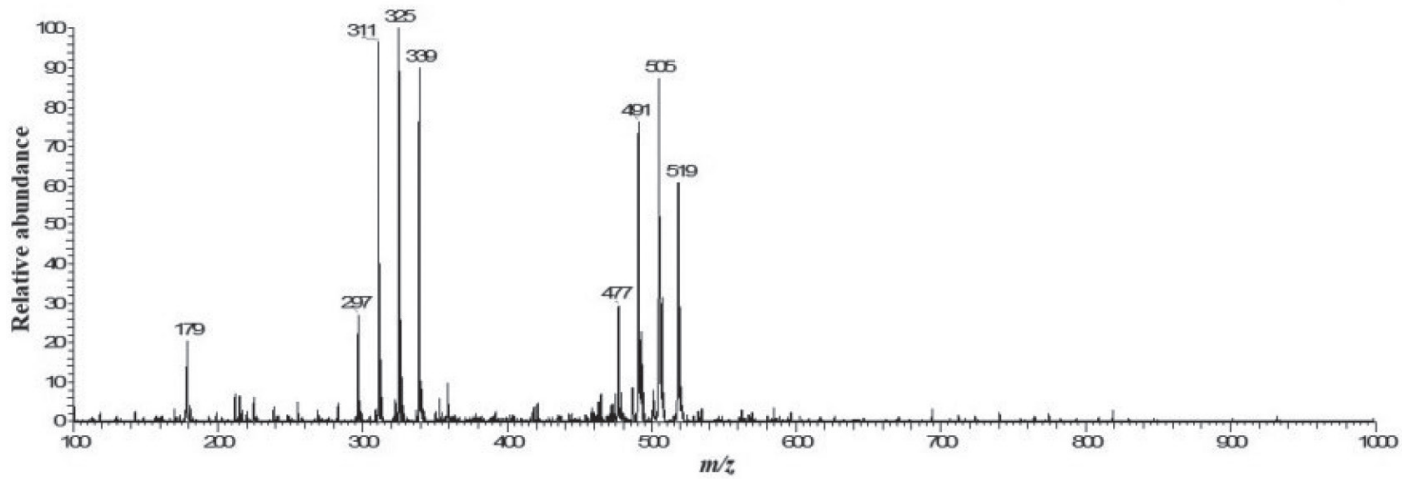

Figure 2. Spectra obtained from Sample B. Representation of (a) PS (+) and (b) (-) PS-MS

Table 4. Proposed classification for ions identified in the beverage samples by ${ }^{a}(+)$ PS-MS

\begin{tabular}{cccccc}
\hline$m / z^{\mathrm{b}}$ & MS/MS & Attempted identification & Chemical class & Reference & Mixed beverage samples \\
\hline 383 & 221 & Syringoyl hexoside & Phenolic compound & Di Fonzo et al..$^{32}$ & A, B, C and G \\
399 & 335 & 4-Hydroxy-2,5-dimethyl-3(2H)-furanone malonyl & Furanone & Di Fonzo et al. ${ }^{32}$ & G \\
\hline
\end{tabular}

${ }^{\mathrm{a}}(+)$ PS-MS: Paper Spray Ionization Mass Spectrometry in the positive mode, ${ }^{\mathrm{b}} \mathrm{m} / \mathrm{z}$ : mass-to-charge ratio, ${ }^{\mathrm{c}} \mathrm{MS} / \mathrm{MS}$ : Sequential Mass Spectrometry.

Table 5. Proposed classification for ions identified in mixed beverage samples by ${ }^{\mathrm{a}}(-)$ PS-MS

\begin{tabular}{|c|c|c|c|c|c|}
\hline${ }^{\mathrm{b}} \mathrm{m} / \mathrm{z}$ & ${ }^{\mathrm{c}} \mathrm{MS} / \mathrm{MS}$ & Attempted identification & Chemical class & Reference & Mixed beverage samples \\
\hline 179 & 71,89 & Hexose & Sugar & Silva et al..$^{33}$ & $\mathrm{~A}$ and $\mathrm{F}$ \\
\hline 311 & 133 & Caftaric acid & Phenolic compound & $\begin{array}{l}\text { Abu-Reidah } \text { et al. }{ }^{34} \\
\text { Silva } \text { et }_{\text {al. }}{ }^{33}\end{array}$ & $\mathrm{~A}, \mathrm{~B}, \mathrm{C} \mathrm{E}$ and $\mathrm{G}$ \\
\hline 323 & 245 & 7 Hydroxycoumarin 7 glucoside (Skimmin) & Phenolic compound & Baskaran et al. ${ }^{35}$ & G \\
\hline 325 & 119,145 & Hexoside P-Coumaric acid & Phenolic compound & Silva et al. ${ }^{33}$ & $\mathrm{~B}, \mathrm{C}, \mathrm{E}$ and $\mathrm{G}$ \\
\hline 339 & 251,295 & Cafeoil-2-hydroxyethane-1, 1.2-tricarboxylic acid & Phenolic compound & Ben Said et al. ${ }^{36}$ & $\mathrm{~A}, \mathrm{~B}, \mathrm{C}, \mathrm{E}$ and $\mathrm{G}$ \\
\hline 359 & $161,179,197$ & Rosmarinic acid & Phenolic compound & $\begin{array}{l}\text { Llorent-Martínez et al. }{ }^{37} \\
\text { Abu-Reidah } \text { et al. }{ }^{38}\end{array}$ & $\mathrm{~A}, \mathrm{D}$ and $\mathrm{F}$ \\
\hline 491 & 447,429 & Oleanane Typotriterpenoids & Triterpene & Salih et al. ${ }^{39}$ & $\mathrm{~B}, \mathrm{C}, \mathrm{E}$ and $\mathrm{F}$ \\
\hline 505 & 445 & $\begin{array}{c}\text { 3.5-Diacetoxi-7-(3.4-di-hydroxy-5-metho- } \\
\text { xyphenyl)-1-(4-hydroxy-3.5-dimethoxyphenyl) } \\
\text { Heptane }\end{array}$ & Diarylheptanoid & Jiang et al. ${ }^{40}$ & $\mathrm{~B}, \mathrm{C}$ and $\mathrm{E}$ \\
\hline
\end{tabular}

a(-) PS-MS: Paper Spray Ionization Mass Spectrometry in the negative mode, ${ }^{\mathrm{b}} \mathrm{m} / \mathrm{z}$ : mass-to-charge ratio, ${ }^{\mathrm{c}} \mathrm{MS} / \mathrm{MS}$ : Sequential Mass Spectrometry.

The use of PS-MS in negative ionization mode allowed the identification of eight compounds belonging to the chemical classes of carbohydrates, phenolic compounds, triterpene and diarilheptanoides. Most of these substances refer to phenolic compounds, which have been related to beneficial effects on the organism, mainly antioxidant activity. ${ }^{41}$

It is noteworthy that the compound with a $\mathrm{m} / \mathrm{z}$ of 311 was found in samples A, B, C, E and G, or most beverages. The common ingredients among these samples were the vegetables (cabbage, spinach, parsley and mint). This compound, formerly identified as caftaric acid by AbuReidah et al. ${ }^{34}$ is a type of phenolic acid, abundant in plants and has already been found in grape. ${ }^{41} \mathrm{~A}$ previous study described the use of this compound to the growth of neoplastic cells. ${ }^{42}$ Zhang et al. ${ }^{43}$ in an in vitro study identified caftaric acid in grape juice and its beneficial effects on the genotoxicity of heterocyclic amines in human-derived cells. In the same beverage samples the compound $m / z, 339$ has been found, attributed by Ben Said et al. ${ }^{36}$ as caffeoil-2-Hydroxyethane-1, 1, 2-tricarboxylic acid, classified as a hydroxycinnamic acid. Lin 
and Harnly ${ }^{44}$ identified 13 hydroxycinnamic acid derivatives in three species of Brassica family, including cabbage, an ingredient present in the samples that were examined in this work.

Another compound that deserves prominence, identified as rosmarinic acid $(\mathrm{m} / \mathrm{z}, 359)$ that was found in samples A, D and F, presents anti-inflammatory action and has anti-pathogenic properties against bacterial and viral agents and neuroprotective effects. ${ }^{37,38,43}$ According to El-Zaeddi et $a l .{ }^{45}$ rosmarinic acid has already been reported in aromatic herbs. The samples A and B have the presence of parsley (Petroselinum crispum) an aromatic herb as a common ingredient among the samples.

\section{CONCLUSION}

The mixed drinks of fruits and vegetables analyzed showed differences in physicochemical composition and the presence of compounds with antioxidant activity that differ among the samples. It is believed that the differences are due to the proportion and constituents of each beverage not being uniform, justifying the variation.

The PS-MS demonstrated to be an innovative technique for obtaining the fingerprint of mixed beverages. Comparison of the ions detected in the spectra of the samples with references in the literature allowed the identification of different compounds such as phenolic acids, sugar, triterpene and diarylheptanoid, compounds proven to be related to beneficial biological activities. To date, no studies have been found in the literature on the attempt to identify chemical constituents in mixed fruit and vegetable beverages.

\section{REFERENCES}

1. Hart, S.; Marnane, C.; Mc Master, C.; Thomas, A. J.; Eating Disorders 2018, 6, 1 .

2. Schwingshackl, L.; Hoffmann, G.; Kalle-Uhlmann, T.; Arregui, M.; Buijsse, B.; Boeing, H.; PLoS One 2015, 10, 1.

3. Bastos, D. H. M.; Rogero, M. M.; Arêas, A. G.; Arq. Bras. Endocrinol. Metabol. 2009, 53, 646.

4. Siqueira, A. D. M. O.; Moreira, A. C. C. G.; Melo, E. D. A.; Stamford, T. C. M.; Stamford, T. L. M.; Rev. Bras. Frutic. 2015, 37, 1020.

5. Silva, R. M.; Figueirêdo, R. M. F de; Queiroz, A. J de M; Feitosa, R. M.; Green Journal of Agroecology and Sustainable Development 2016 , 11,65 .

6. Preti, R.; Rapa, M.; Vinci, G.; J. Food Qual. 2017.

7. Wruss, J.; Lanzerstorfer, P.; Huemer, S.; Himmelsbach, M.; Mangge, H.; Höglinger, O.; Weghuber, D.; Weghuber, J.; Nutr. J. 2015, 14, 32.

8. Alissa, E. M.; Ferns, G. A.; J. Nutr. Metab. 2012, 16.

9. Singleton, V. L.; Orthofer, R.; Lamuela-Raventos, R. M.; Methods Enzymol. 1999, 299, 152.

10. Rufino, M. S. M.; Alves, R. E.; Brito, E. S.; Morais, S. M.; Sampaio, C. G.; Pérez-Jiménez, J.; Fulgêncio, D. S. C. C.; Metodologia Científica: Determinação da Atividade Antioxidante Total em Frutas pela Captura do Radical Livre ABTS +, Fortaleza, 2007.

11. Deng, J.; Yang, Y.; Anal. Chim. Acta 2013, 785, 82.

12. Assis, C.; Pereira, H. V.; Amador, V. S.; Augusti, R.; Oliveira, L. S.; Sena, M. M.; Food Chem. 2018, 281, 71.

13. Wang, H.; Liu, J.; Cooks, R. G.; Ouyang, Z.; Angew. Chem. 2010, 49, 877.

14. Taverna, D.; Di Donna, L.; Mazzotti, F.; Tagarelli, A.; Napoli, A.; Furia, E.; Sindona, G.; J Mass Spectrom. 2016, 51, 761.

15. Freire, A. C. S.; Araújo, L. B.; Brazilian Magazine of Sports Nutrition 2017, 11, 536 .
16. Klein, A. V.; Kiat, H.; Journal of Human Nutrition and Dietetics 2015 , 675.

17. Association of Official Analytical Chemists, Official methods of the Association of the Agricultural Chemists, 20 a ed., Maryland, USA, 2016.

18. Bligh, E. G.; Dyer, W. J. A.; Can. J. Biochem. Physiol. 1959, $27,911$.

19. Rufino, M. S. M.; Alves, R. E.; Brito, E. S.; Pérez-Jiménez, J.; SauraCalixto, F.; Mancini-Filho, J.; Food Chem. 2010, 121, 996.

20. Bezerra, C. V.; Silva, L. H. M.; Costa, R. D. S.; Mattietto, R. A.; Rodrigues, A. M. C.; Braz. J. Food Technol. 2013, 16, 155.

21. Feiber, L. T.; Caetano, R.; Aliment. Nutr. 2012, 23, 141.

22. Brum, D. C. M.; Mallet, A. C. T.; Saron, M. L. G.; Souza, E. B.; Costa, L. M. A. S.; DEMETRA: Food, Nutrition \& Health 2014, 9, 943.

23. Carvalho, A. V.; Mattietto, R. A.; Beckman, J. C.; Braz. J. Food Technol. 2017, 20, 1 .

24. Moura, S. C. S. R.; Vissotto, F. Z.; Berbari, S. A. G.; Souza, E. C. G.; Toti, F. G. P.; Alves Júnior, P.; Food Sci Technol. 2017, 37, 216.

25. Faraoni, A. S.; Ramos, A. M.; Guedes, D. B.; Oliveira, A. N.; Lima, T. H. S. F.; Sousa, P. H. M.; Rural Sci. 2012, 42, 91.

26. Machado, P. G.; Speroni, C.; Ferraz, J. F.; Figleski, P. D.; Koch, R. H.; Severo, J.; Journal of the Southern Brazilian Congress of Food Engineering 2018, 3, 01.

27. Figueira, R; Nogueira, A. M. P.; Venturini Filho, W. G.; Ducatti, C.; Queiroz, É. C.; Pereira, A. G. S.; Alimentos e Nutrição Araraquara 2010, 21, 267.

28. Oniszczuk, A.; Olech, M.; Ind. Crops Prod. 2016, 83, 359.

29. Murador, D. C.; Mercadante, A. Z.; De Rosso, V. V.; Food Chem. 2015, 196, 1101.

30. Fu, L.; Xu, B. T.; Xu, X. R.; Gan, R. Y.; Zhang, Y.; Xia, E. Q.; Li, H. B.; Food Chem. 2011, 129, 345.

31. Bamidele, O. P.; Fasogbon, M. B.; Food Chem. 2017, 220, 184.

32. Difonzo, G.; Vollmer, K.; Caponio, F.; Pasqualone, A.; Carle, R.; Steingass, C. B.; Food Control. 2019; 96, 260.

33 Silva, M. R.; Freitas, LG, Souza, A. G.; Araújo, R. L. B.; Lacerda, I. C. A.; Pereira, H. V.; Augusti, R.; Melo, J. O. F.; J. Braz. Chem. Soc. 2019, $30,1034$.

34. Abu-Reidah, I. M.; Ali-Shtayeh, M. S.; Jamous, R. M.; Arráez-Román, D.; Segura-Carretero, A.; Food Chem. 2015, 166, 17.

35. Baskaran, R.; Pullencheri, D.; Somasundaram, R.; Food Res. Int. 2016, 82, 121.

36. Ben Said, R.; Hamed.; A. I.; Mahalel, U. A.; Al-Ayed, A. S.; Kowalczyk, M.; Moldoch, J.; Oleszek, W.; Stochmal, A.; Int. J. Mol. Sci. 2018, 18, 512.

37. Llorent-Martinez, E. J.; Spinola, V.; Gouveia, S.; Castilho, P. C.; Ind. Crops Prod. 2015, 69, 80.

38. Abu-Reidah, I. M.; Arráez-Román, D.; Al-Nuri, M.; Warad, I.; SeguraCarretero, A.; Food Chem. 2019, 279, 128.

39. Salih, E.; Fyhrquist, P.; Abdalla, A.; Abdelgadir, A.; Kanninen.; M, Sipi, M.; Antibiotics 2017, 6, 37.

40. Jiang, H.; Timmermann, B. N.; Gang, D. R.; Rapid Commun. Mass Spectrom. 2007, 21, 509.

41. Shahidi, F.; Ambigaipalan, P.; J. Funct Foods 2015, 18, 820.

42. Chen, H-J.; Inbaraj, B. S.; Chen, B-H.; Int. J. Mol. Sci. 2012, 13, 260.

43. Zhang, M.; Yan, H.; Li, S.; Yang, J.; Brain Res. 2017, 1657, 9.

44. Lin, L. Z.; Harnly, J. M.; J. Agric. Food Chem. 2009, 57, 7401.

45. El-Zaeddi, H.; Calín-Sánchez, Á.; Nowicka, P.; Martínez-Tomé, J.; Noguera-Artiaga, L.; Burló, F.; Wojdyło, A.; Carbonell-Barrachina.; A. A.; Food Chem. 2017, 226, 179. 